\title{
ECONOMIC DYNAMICS OF INDUSTRIAL ENTERPRISES DEVELOPMENT IN THE ECONOMY OF THE EMERGING TYPE
}

The article examines the prerequisites for financial support of industrial development in the emerging economy and the stability of the national currency. It is noted that the dynamics of inflation indices are characterized by constant fluctuations, and industrial production indices are lower than the threshold values. Indices of industrial production by types of activity are considered. The dynamics of profitability of industrial enterprises over the last decade, which is characterized by a wavy nature, is analyzed. The analysis of dynamics of volumes of the realized industrial production on kinds of activity is carried out. It is determined that the low level of competitiveness of the innovative potential of industrial production begins with significant losses of previous business partners from other activities of the national economy, as industry is one of the first industries to form value chains and is inextricably linked with integration business processes. The dynamics of indicators of financing of innovative activity of industrial enterprises is analyzed, and it is noted that today it remains in a larger volume - own funds of enterprises and organizations. The main reason for Ukraine's industrial failures remains the inconsistency of the innovative potential of Ukrainian industrial producers with world standards and the consistently low share of innovative enterprises, along with significant debt burdens on both the state budget and industrial production. The financial results (profit / loss) by types of industrial enterprises are studied. The peculiarities of growth and decline of net profit are determined and its dynamics during the last ten years is illustrated. The reasons for changes in the dynamics of profitability, which significantly affected the financial and economic performance of industrial enterprises in the country. Ways to prevent significant indicators of unprofitability of industrial enterprises, where it is extremely important to implement foreign experience in the implementation of concession agreements, and innovations of low-waste technologies, energy efficiency, resource conservation, with the introduction of closed production cycles and zero technologies.

Key words: indices of industrial production, net profit, industry, innovation, emergence economy, circular economy, closed production cycle.

DOI: https://doi.org/10.32838/2523-4803/70-3-22

УДК 331.1:631.11

Дюк А. A.

кандидат економічних наук, доцент,

Вінницький національний аграрний університет

Diuk Anna

Vinnytsia National Agrarian University

\section{СОЦІАЛЬНО-ЕКОНОМІЧНА РЕЗУЛЬТАТИВНІСТЬ СІЛЬСЬКОГОСПОДАРСЬКОГО ПІДПРИЕМНИЦТВА: РЕГІОНАЛЬНИЙ АСПЕКТ ОЦІНКИ}

\footnotetext{
У статті розглянуто теоретико-методичні характеристики наукового позиціювання сочіальноекономічної результативності сільськогосподарського підприємництва. Запропоновано науково обтрунтований підхід до визначення соціально-економічної результативності та засади відмінностей від поняття соиіально-економічної ефективності підприємницького господарювання. Охарактеризовано зв'язок діяльності у сільськогосподарському підприємництві із розвитком сільських територій, зазначено про регіональну специифіку значущьості агробізнесу для села, формування продовольчої безпеки. Доведено сутність підприємництва як соиіального та економічного явища, щзо забезпечує сочіально-економічну результативність. Проаналізовано зв'язок структури сільськогосподарського виробництва, регіональні особливості за часткою валової продукції як базового індикатора сочіальноекономічної результативності підприємництва. Окреслено перспективність подальшого дослідження підприємництва з представленням усе більшої значущості галузі в умовах економічної невизначеності.

Ключові слова: підприсмництво, сільськогосподарське підприємниџтво, сочіально-економічна результативність, господарювання, продуктивність, регіональний розвиток.
}

Постановка проблеми. Розвиток регіональних соціально-економічних систем в Україні, розбудова їхньої перспективи нерозривно пов'язані з сільськогос- подарським підприємництвом. Так склалося історично, що фізична спроможність більшості українських сіл досягти прийнятного рівня добробуту залежить від 
сільського господарства. Відповідним чином ефективність діяльності сільськогосподарських підприємств завжди характеризується пріоритетною значущістю для економіки, держави, суспільства, особливо в умовах кризи і передбачуваної турбулентності соціальноекономічної системи, підприємницької та суспільної невизначеності. Тому фактично вічною, постійною у необхідності пошуку науково-практичних шляхів вирішення є проблема забезпечення розвитку, соціально-економічної результативності сільськогосподарського підприємництва, у тому числі структурованого за регіональним розміщенням. Проблематика розвитку підприємництва як діяльності в економіці, сільськогосподарській галузі, а також господарська діяльність за регіональним розміщенням організацій досить грунтовно вивчена, але потребує адаптивної характеристики щодо вітчизняних реалій.

Аналіз останніх досліджень і публікацій. Дослідження підприємництва представлені у працях цілої когорти відомих учених як у загальноекономічному, так і в галузевому вираженні фундаментальних та прикладних аспектів. Фундамент вивчення теорії й практики позиціювання цього соціально-економічного феномена закладено втіленням ідей Р. Кантільона [1], А. Сміта [2], Й. Шумпетера [3], Т. Веблена [4], продовжено і розвинуто працями 3. Варналія [5], В. Андрійчука [6], у тому числі щодо розвитку сільськогосподарського підприємництва, соціально-економічної результативності, включаючи вивчення регіональних особливостей, - Ю. Лупенка [7; 8], М. Маліка [8], Л. Романової [9], О. Шпикуляка [10], А. Сави [11], П. Саблука [12] та інших науковців [13 - 16].

Враховуючи грунтовні дослідження і величезні здобутки науки про підприємництво, функціонування підприємств і формування їхньої ефективності в сільському господарстві, відзначимо, що актуальним для вітчизняного середовища залишається питання соціально-економічної результативності сільськогосподарського підприємництва, зокрема в аспектах регіонального розвитку.

Формулювання цілей статті. Основна мета дослідження полягає в тому, щоб визначити теоретичні положення змісту соціально-економічної результативності сільськогосподарського підприємництва, охарактеризувати загальні та регіональні аспекти оцінки динаміки їі досягнення.

Виклад основного матеріалу дослідження. Теорія підприємницького господарювання є сформованою на достатньому рівні пізнання процесу економічних, соціальних, господарських відносин у ринковій системі. Загальну теоретичну модель підприємництва запропонував Р. Кантільон [1] - змістовні характеристики визначення цього поняття, які практично не змінилися. Чинники підприємництва, у тому числі в сільськогосподарському секторі, визначено в класичній праці А. Сміта [2] - предметно соціально-економічну результативність господарювання через призму засад розвитку добробуту, який формується у процесі товарообміну між міськими і сільськими мешканцями [2, с. 291]. Щодо загальної соціально-економічної результативності сільськогосподарських підприємств, то доведеним практикою є висновок А. Сміта [2, с. 291] про те, що «село забезпечує місто продуктами харчування та матеріалами для переробки. Місто оплачує це постачання тим, що відсилає частину готових виробів мешканцям села» [2, с. 291]. Така форма реалізації соціально-економічної результативності відноситься до діяльності сільськогосподарських підприємств, що відповідає природі цієї форми бізнесу. Соціальноекономічна специфіка в основі галузевого господарювання: «Оскільки за природою речей продукти харчування становлять потребу, що стоїть на першому місці порівняно з предметами зручності й розкоші, то галузь, що дає їх, має передувати тим галузям, що виробляють решту» [2, с. 292]. Тобто сільське господарство має першочергове соціально-економічне значення, формує результати, втілені у забезпеченні функціонування усіх систем, у яких бере участь людина, адже задовольняє продовольчі й екологічні потреби, тобто базові для життя. Й. Шумпетер [3], зазначаючи про економічний обмін у підприємницькій господарській системі, наголошує про соціальні аспекти їі розвитку: «Факт ніколи не буває винятково чи суто економічним - завжди існують інші, нерідко важливіші аспекти» [3, с. 21]. Він також відзначив функцію підприємця як суб'єкта, який втілює нові комбінації ресурсів, виробничих факторів для отримання прибутку [3, с. 82-85]. Тобто підприємництво реалізує господарську діяльність для формування соціально-економічної результативності у досягненні добробуту населення, яке сплачує за вироблений продукт певну ціну.

Вітчизняні науковці вважають підприємництво «еволюційно зумовленою соціальною формою реалізації підприємливості індивідів, публічною діяльністю, спрямованою на досягнення ними власних цілей через задоволення (пряме чи опосередковане) потреб людей» [8, с. 7]; воно «вже давно постало не лише як економічне явище, воно усебічно соціалізоване у створену людиною систему соціально-економічного поступу - наслідує глобальний контекст своєї значущості, адже лише завдяки підприємництву соціум набуває «статусу» продуктивності» [16, с. 9]. Сутність цього явища також інтерпретовано як «мистецтво ділової активності, передусім розумовий процес, який реалізується у формі ділового проектування через уміння організувати бізнес і досить успішно здійснювати функції, пов'язані 3 веденням власної справи» [5]. При цьому відзначається, що «соціальноекономічний процес в умовах вітчизняного сільського розвитку $є$ проблемним за відсутності ефективних механізмів консолідації соціальних і виробничо-господарських систем, інституцій, які сприятимуть стабілізації розвитку сільської території як життєвого та виробничого середовища» [8, с. 79]; серед пріоритетів вивчення проблеми також доведена виключна роль соціального капіталу [8; 15]. 
Соціально-економічна результативність сільськогосподарського підприємництва, сформована за рівнем соціальної ціни виробництва на регіональному рівні, впливає на соціальний потенціал сільських територій. Тобто сільськогосподарські підприємства ефективністю й особливо виконанням селозберігаючих функцій забезпечують економічну соціалізацію господарювання. Доречною з цього приводу вважаємо позицію науковців Національного наукового центру «Інститут аграрної економіки» про те, що «мтратегічною метою у сфері розвитку підприємництва на селі $є$ формування конкурентного підприємницького середовища, спроможного забезпечити зайнятість і зростання доходів працездатного сільського населення, просування сільськогосподарської продукції на максимально вигідних для сільськогосподарських товаровиробників умовах, збільшення доходів сільських підприємств, домогосподарств і громад» [13, с. 36].

Соціально спрямовані виробничі витрати, або ж, як ми вважаємо, соціальна ціна виробництва - опосередкована оцінка рівня соціальної відповідальності сільськогосподарського підприємництва. Бо з погляду селянина-працівника бізнес, який витрачає більший обсяг грошей на соціально спрямовані витрати, є кращим за рівнем соціальної відповідальності. Соціальна відповідальність - загальний критерій соціально-економічної результативності, корисності бізнесу для територій.

Соціально-економічна результативність підприємств у сільському господарстві виходить далеко за межі класичних індикаторів. Це по своїй суті має бути соціально відповідальний бізнес, бо культивується на селі як спосіб життя і господарювання. Наводячи думки інших дослідників, підтверджуємо правильність такої постановки питання у контексті засад формування i поширення соціально-еконоімчної результативності господарювання. Наприклад, у силу різних організаційно-економічних причин, галузевих трансформацій основна частина зайнятих в сільському господарстві перебуває в особистому секторі - сфері самозабезпечення. В окремих регіонах, наприклад Тернопільській області, «в господарствах населення самоексплуатується величезна кількість прихованих безробітних (80-90\% від усіх зайнятих у галузі регіону)» [11, с. 6].

Зазначене наштовхує на теоретико-методичне розуміння соціально-економічної результативності підприємництва, що відповідає чиннику підприємливості і користі, яку приносить підприємець своєю діяльністю на ринку, формуючи певний рівень добробуту населення. Вважаємо, що соціально-економічна результативність у такому разі означає результати, утворені підприємством і споживані суспільством, а також безпосередніми учасниками виробничо-господарського процесу. У сільському господарстві задіяний також чинник сільської території як місце безпосереднього розміщення сільськогосподарських підприємств. На локальному рівні (підприємство, сільська територія) соціально-економічна результативність характеризується показниками рівня заробіт- ної плати, тобто витрат на оплату праці, віднесених на собівартість виробництва продукції; відрахувань на соціальні заходи; витрат на орендну плату за земельні частки (паї) і майнові паї, якими володіють працівники, зайняті на виробництві; обсягу вкладень підприємця у розвиток сільської території, інфраструктури тощо. Локальна соціально-економічна результативність, притаманна кожному конкретному підприємству порівняно з іншими підприємствами, трансформується у конкурентоспроможність.

Економічна модель господарювання в сільському господарстві України все більше прямує від селозберігаючої моделі до латифундійної, за якої на перше місце виходять підприємницькі результати, а соціальна складова частина (соціально-економічна) замикається на задоволенні нормативно-встановлених, за потреби кон'юнктурних вимог до рівня зарплати, відрахувань на соціальні заходи, орендної плати. Тому структура виробництва, видовий склад сільськогосподарських продуктів, а також розміри господарств - базові визначники соціально-економічної результативності сільськогосподарського підприємництва.

Регіональні особливості формування ефективності сільськогосподарського виробництва пов'язуються 3 спеціалізацією, природно-кліматичними умовами, які дають змогу вести господарство у певний спосіб. Наприклад, у Карпатському регіоні, на відміну від степової зони, великотоварні господарства майже відсутні через ландшафтні особливості, невеликі розміри земельних ділянок тощо. Тобто відзначається специфіка набору культур у рослинництві і тварин у тваринництві, на виробництві яких засноване господарювання підприємців. Зазначене впливає на структуру зайнятості сільського населення, потреби підприємств у працівниках, позначається на основах механізму мотивації праці. Склад підприємств, структура виробничої системи за напрямами господарювання формує соціально-економічну результативність.

Для визначення соціально-економічної результативності сільськогосподарських підприємств представляємо гіпотезу про те, що підприємства із спеціалізацією на трудомістких виробництвах культивують вищий рівень соціально-економічних витрат, тобто сплачують вищу соціальну ціну виробництва.

Першооснова досягнення соціально-економічних результатів підприємницького господарювання - ефективність господарського комплексу. Ефективність означає спроможність підприємницького механізму досягати високих виробничих, економічних, соціальних результатів. Соціальна, соціально-економічна ефективність - балансів продовольчої безпеки, умов розвитку сільських територій, справедливої оплати праці персоналу, екологічних умов тощо.

Практичну реалізацію функції виробництва сільськогосподарської продукції в Україні на регіональному рівні здійснюють сільськогосподарські підприємства та господарства населення (табл. 1). У цих суб'єктах ринку відбувається процес поєднання праці 
і капіталу, формується продуктивність. Основна частина трудомісткої продукції, виробництво якої потребує великої кількості зайнятих, зосереджена у господарствах населення. Це непідприємницького статусу суб'єкти, які першочергово зорієнтовані на виконання функції самозабезпечення.

Згідно з оцінкою структурних тенденцій (табл. 1 i рис. 1), а також регіональних трендів часток виробництва валової продукції (табл. 2) за критерієм створення трудомістких іiі видів, кращу соціально-економічну результативність формують господарства населення.

Сільськогосподарські підприємства виробляють переважно експортооріснтовану рослинницьку продукцію (див. табл. 1). У результаті такої побудови господарського механізму соціальна ціна виробництва нижча від тієї, яка могла би бути у разі функціонування збалансованої господарської структури.
Результати розвитку сільського господарства формують місце регіону в загальнодержавній структурі в Україні (табл. 2), а також визначають регіональні тренди підприємств за соціально-економічними показниками (табл. 3).

Протягом 2016-2018 pр. найвищий (за часткою) обсяг валової продукції був вироблений суб'єктами господарювання Вінницької області, а найнижчий - Закарпатської і Луганської. Причина - виражений аспект спеціалізації, особливих природно-економічних умов господарювання. Наприклад, сільгоспвиробники Вінницької області виробили від 6 до 13\% валової продукції, а Луганської і Закарпатської - не більше 2\% (табл. 2). Тобто у кожному з регіонів здобувається відповідний рівень соціально-економічної результативності.

Виробники сплачують відповідну соціальну ціну несуть соціально спрямовані витрати з розрахунку на

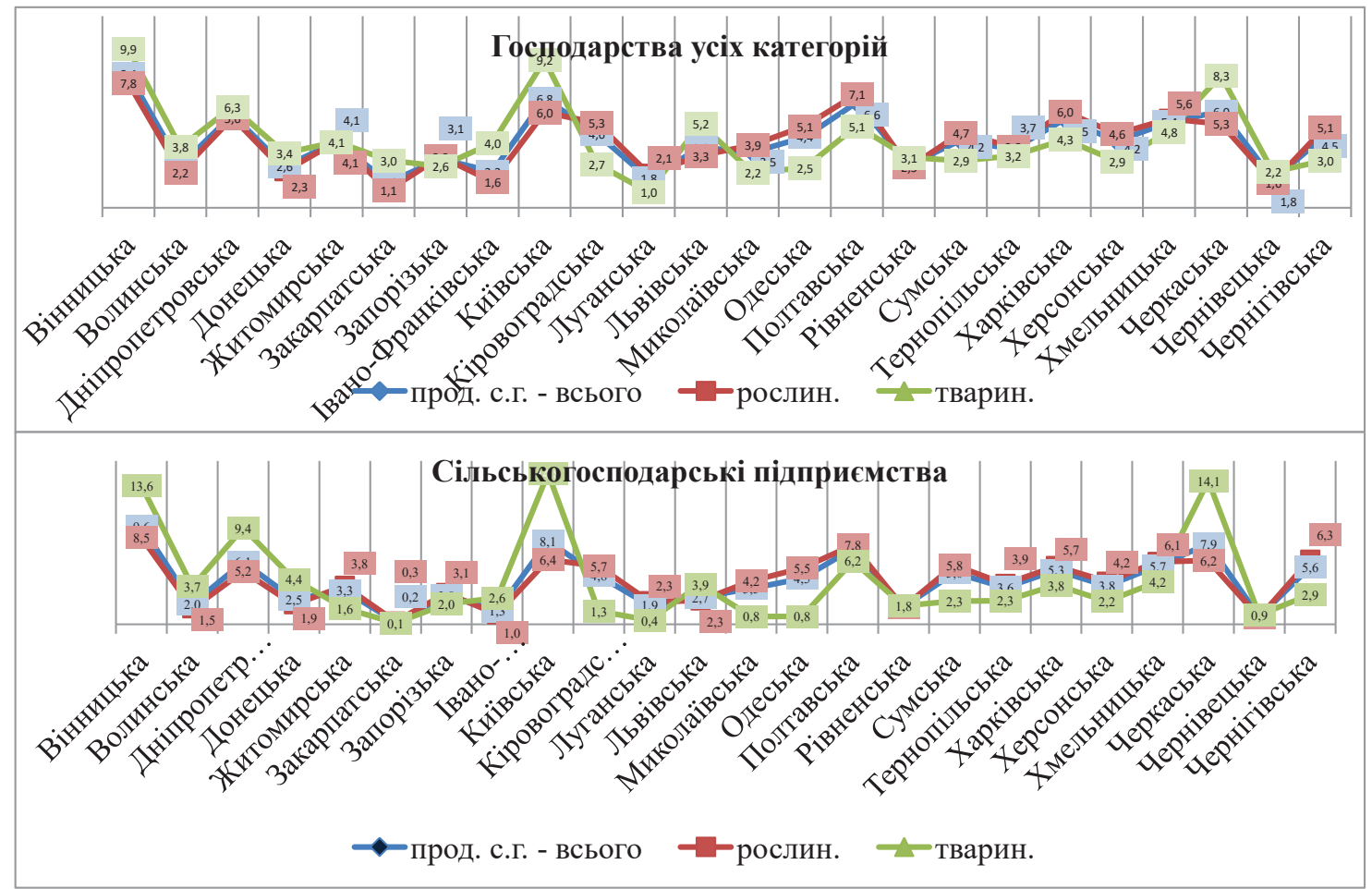

Рис. 1. Регіональні частки виробництва сільськогосподарської продукції в Україні, 2018 р.

Джерело: розраховано і побудовано за даними Державної служби статистики Украӥни [17]

Таблиця 1

Аналіз структури виробництва продукції сільського господарства в Україні за категоріями виробників

\begin{tabular}{|c|c|c|c|c|c|c|c|c|c|}
\hline \multicolumn{6}{|c|}{ Частки у загальнодержавному виробництві продукції у постійних цінах 2010 року за категоріями виробників, } \\
$\%$ до загального обсягу по Україні,\% \\
\hline \multirow{2}{*}{ рік }
\end{tabular}

Джерело: розраховано і наведено за даними Державної служби статистики України [17] 
Таблиця 2

Розподіл регіонів за часткою у загальнодержавному виробництві продукції сільського господарства (у постійних цінах 2010 року за категоріями виробників, \% до загального підсумку по Україні)

\begin{tabular}{|c|c|c|c|c|c|c|c|c|c|c|}
\hline \multicolumn{2}{|c|}{ Частки у загальнодержавному виробництві продукції у постійних цінах 2010 року за категоріями виробників, } \\
\% до загального обсягу по Україні
\end{tabular}

Джерело: розраховано і наведено за даними Державної служби статистики Украйни [17]

Таблиця 3

Регіональні тренди розвитку сільськогосподарських підприємств за соціально-економічними показниками по Україні*

\begin{tabular}{|c|c|c|c|c|}
\hline Показники & 2015 & 2016 & 2017 & 2018 \\
\hline \multicolumn{5}{|c|}{ Соціально спрямовані витрати виробництва у підприємствах, \% у структурі } \\
\hline $\begin{array}{l}\text { Прямі витрати } \\
\text { на оплату праці }\end{array}$ & $\begin{array}{l}\max -\text {-Донецька }-7,0 \% \\
\min -\text { Волинська- 4,1\% }\end{array}$ & $\begin{array}{c}\max \text {-Закарпатська - } \\
\text { 7,4\% } \\
\min -\text { Волинська- 3,6\% }\end{array}$ & $\begin{array}{c}\text { max -Закарпатська - } \\
7,4 \% \\
\min \text { - Чернігівська - } \\
\text { 2,3\% }\end{array}$ & $\begin{array}{c}\text { max -Закарпатська - } \\
8,2 \% \\
\min -\text { Івано- } \\
\text { Франківська }-4,0 \%\end{array}$ \\
\hline $\begin{array}{c}\text { Відрахування } \\
\text { на соціальні заходи }\end{array}$ & 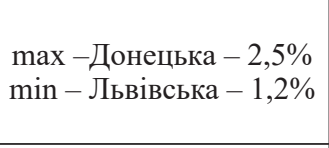 & $\begin{array}{c}\max -\text { Закарпатська - } \\
\text { 1,7\% } \\
\min -\text { Волинська- 0,8\% }\end{array}$ & $\begin{array}{c}\max \text {-Закарпатська - } \\
1,7 \% \\
\min \text { - Чернігівська - } \\
0,5 \%\end{array}$ & $\begin{array}{c}\text { max -Закарпатська - } \\
1,9 \% \\
\text { min - Івано- } \\
\text { Франківська - 0,8\% }\end{array}$ \\
\hline $\begin{array}{c}\text { Орендна плата } \\
\text { за земельні частки (паї) }\end{array}$ & $\begin{array}{c}\text { max -Луганська - } \\
13,0 \% \\
\min \text { - Закарпатська - } \\
\text { 2,0\% }\end{array}$ & $\begin{array}{c}\text { max -Полтавська - } \\
15,0 \% \\
\min -\text { Волинська - } \\
4,0 \% \\
\end{array}$ & $\begin{array}{c}\max \text {-Полтавська - } \\
\text { 14,8\% } \\
\min \text { - Чернігівська - } \\
\text { 3,7\% }\end{array}$ & $\begin{array}{c}\max \text {-Полтавська - } \\
13,9 \% \\
\min -\text { Волинська - } \\
4,0 \% \\
\end{array}$ \\
\hline $\begin{array}{l}\text { Орендна плата } \\
\text { за майнові паї }\end{array}$ & $\begin{array}{c}\text { max -Закарпатська - } \\
\text { 0,9\% } \\
\min -\text { Запорізька - } \\
0009 \%\end{array}$ & $\begin{array}{c}\max \text {-Закарпатська - } \\
1,5 \% \\
\text { min -Івано- } \\
\text { Франківська - 0,0004\% }\end{array}$ & $\begin{array}{c}\max \text {-Закарпатська - } \\
4,7 \% \\
\min -\text { Харківська - } \\
0,003 \% \\
\end{array}$ & $\begin{array}{c}\max \text {-Житомирська - } \\
\text { 0,2\% } \\
\min \text { - Рівненська - } \\
0,0003 \% \\
\end{array}$ \\
\hline
\end{tabular}

Джерело: наведено і розраховано з даних Державної служби статистики України [17]

земельну площу і з розрахунку на зайнятого у виробництві. За більшого обсягу валової продукції створюється більше робочих місць, що в умовах соціальноекономічної кризи дуже важливо.

Залежно від структури виробництва формуються регіональні тренди розвитку сільськогосподарських підприємств за соціально-економічними показниками (табл. 3). До складу соціально-економічних показників результативності підприємницького господарювання відносимо: прямі витрати на оплату праці, відрахування на соціальні заходи, орендну плату за земельні частки (паї).

Динаміка соціально-економічних показників результативності виробничо-господарської діяльності у підприємницьких структурах також має регіональні особливості. Аналітика таблиці 3 підтверджує зв'язок між галузевою структурою, спеціалізацією і рівнем соціальної ціни, яку платить підприємство в сільському господарстві. Зокрема, у Закарпатській області, яка загалом несприятлива для великотоварного, експортоорієнтованого виробництва традиційних для України культур (пшениця, соняшник, соя), соціальна ціна виробництва за індикатором «прямі витрати на оплату праці» $є$ найвищою 3-поміж інших регіонів. Це спричинено тим, що вузькоспеціалізоване нішеве виробництво регіонального типу є трудомістким. Також відзначаємо, що певні регіони мають свою власну специфіку 
пріоритетів за складниками соціальної ціни, а значить, формування соціально-економічної результативності. Наприклад, підприємства Полтавської області сплачують найвищу ціну виробництва за індикатором «орендна плата за земельні частки (паї)»; господарі Закарпаття - за роботи працівників (див. табл. 3). Тобто обсяг кадрових ресурсів, земельно-майнових активів i структура виробництва визначають його соціальну ціну, а також соціально-економічну результативність. Регіональні особливості спеціалізації підприємств, таким чином, позначаються на соціально-економічній результативності господарювання. Таким чином, соціальна ціна - вартість, яку підприємство платить за соціальний складник виробництва, - сприймається практично як соціально-економічна результативність щодо зайнятого персоналу.

Висновки. Соціально-економічна результативність сільськогосподарського підприємництва формується у процесі здійснення підприємством статутної господарської діяльності на певній території, в регіоні. Вона $\epsilon$ наслідком ефективного поєднання праці і капіталу, використання земельних ресурсів, що втілюється у показниках добробуту села, рівнях доступності продовольства і продовольчої безпеки, добробуту жителів села тощо. Досягнення високих показників соціальноекономічної результативності діяльності сільськогосподарських підприємств - вкрай важливе завдання, адже аграрна галузь $є$ базовою для економіки в усіх відношеннях. Також в Україні важливий регіональний аспект вирішення проблеми, він яскраво виражений, трансформований у спосіб сільського життя. Це питання потребує подальшого дослідження, є перспективним для наукового пізнання, особливо в умовах невизначеності перспективи інших галузей, а також усе більшого розуміння необхідності перебудови способу організації усього суспільно-економічного життя.

\section{Список літератури:}

1. Кантильон Р. К вопросу о сущности предпринимателей. СПб.: Литера плюс, 2006. 220 с.

2. Сміт Адам. Дослідження про природу і причини багатства народів / пер. 3 англ. О. Васильєв, М. Межевікіна, А. Малівський. Київ, Наш формат, 2018. 736 с.

3. Шумпетер Й.А. Теорія економічного розвитку : дослідж. прибутків, капіталу, кредиту, відсотка та економічного циклу. Київ, 2011. 242 с.

4. Веблен Торстейн. Теория делового предприятия / Перс. с англ. Москва: Дело, 2007. 288 с.

5. Варналій 3.С. Мале підприємництво: основи теорії і практики. Київ. : Знання; КОО, 2001. 277 с.

6. Андрійчук В.Г. Ефективність діяльності аграрних підприємств: теорія, методика, аналіз: монографія. Київ: КНЕУ. 2005. 292 c.

7. Перспективні форми організації господарської діяльності на селі: наук. доп. / Ю. О. Лупенко та ін. Київ : ННЦ «AE», 2019. $114 \mathrm{c}$.

8. Розвиток підприємництва і кооперації: інституціональний аспект : моногр. / [Лупенко Ю.О., Малік М.Й., Заяць В.М. та інші]. Київ, 2016. 430 с.

9. Романова Л.В. Становлення підприємництва в сільському господарстві. Київ. : IAЕ. 1997. 272 с.

10. Шпикуляк О.Г., Малік М.Й. Інституціональний аналіз розвитку підприємництва в аграрному секторі економіки: методичний аспект. Економіка АПК. 2019. № 6. С. 73-82.

11. Науково-практичні рекомендації з обгрунтування методичних підходів щодо ефективної реструктуризації аграрної галузі в умовах сталого розвитку сільських територій / А.П. Сава, М.Г. Саєнко, О.Р. Олійник та ін. Тернопіль. 2015.80 с.

12. Організаційно-економічна модернізація аграрної сфери: наукова доповідь / за заг. ред. акад. НААН П.Т. Саблука. Київ. ННЦ IАE, 2011. 342 с.

13. Стратегічні напрями сталого розвитку сільських територій на період до 2030 року / [Лупенко Ю.О., Малік М.Й., Булавка О.Г. та ін.]; за ред. Ю.О. Лупенка. Київ.: ННЦ IАЕ, 2020. 60 с.

14. Шпикуляк О.Г. Витрати та ефективність виробництва продукції в сільськогосподарських підприємствах (моніторинг) / О.Г. Шпикуляк, Ю.П. Воскобійник, О.В. Овсянніков та ін.; За ред. О.Г. Шпикуляка, Ю.П. Воскобійника, О.В. Овсяннікова. К. 2007. 294 с.

15. Шпикуляк О.Г. Становлення соціального капіталу в аграрній сфері трансформаційної економіки. Management Theory and Studies for Rural Business and Infrastructure Development, Volume 8. Page 28 - 34. Published 2007. URL : http://mts.asu.lt/mtsrbid/article/view/678/704 (дата звернення 23.03.2020).

16. Шпикуляк О.Г. Теоретичні засади розвитку підприємництва в інституційному механізмі ринку / О.Г. Шпикуляк / Розвиток малих аграрних підприємств в ринковому інституційному середовищі: індикатори та ефективність: монографія / Національний науковий центр «Інститут аграрної економіки» [Лупенко Ю.О., Шпикуляк О.Г., Малік М.Й. та ін.]. Київ. ННЦ «IAЕ», 2017. 204 с. С. 8 - 12.

17. Офіційний сайт Державної служби статистики України. URL. http://www.ukrstat.gov.ua (дата звернення 26.03.2020).

\section{References:}

1. Kantylon, R. (2006). To the question of the essence of entrepreneurs. [On the essence of entrepreneurs]. SPb.: Lytera plius. (in Russian) 
2. Smit Adam. (2018) Doslidzhennia pro pryrodu i prychyny bahatstva narodiv [Research on the nature and causes of the wealth of nations]. Kyiv, 736 p. (in Ukrainian)

3. Shumpeter, J.A. (2011). Teoriia ekonomichnoho rozvytku: doslidzhennia prybutkiv, kapitalu, kredytu, vidsotka ta ekonomichnoho tsyklu [Theory of economic development: the study of profits, capital, credit, interest and the economic cycle]. Kyiv: Kyiv-Mohyla Academy (in Ukrainian)

4. Veblen Torstein. (2007). Teoryia delovoho predpryiatyia [Business Enterprise Theory]. Moskva: Delo. 288 p. (in Russian)

5. Varnalii Z.S. (2001). Male pidpryiemnytstvo: osnovy teorii i praktyky. [Small business: the foundations of theory and practice]. Kyiv. : Znannia; KOO. 277 p. (in Ukrainian).

6. Andriichuk, V.H. (2005), Efektyvnist diialnosti ahrarnykh pidpryiemstv: teoriia, metodyka, analiz [Efficiency of agriculture of agricultural enterprises: theory, methodology, analysis]. KNEU, Kyiv. (In Ukrainian).

7. Perspektyvni formy orhanizatsii hospodarskoi diialnosti na seli: [Perspective forms of organization of economic activity in the countryside:] nauk. dop. (2019) / Yu. O. Lupenko ta in. Kyiv : NNTs «IAE». 114 p. (in Ukrainian)

8. Lupenko Yu.O., Malik M.I., Zaiats V.M. ta inshi (2016) Rozvytok pidpryiemnytstva i kooperatsii: instytutsionalnyi aspect: monohr [Entrepreneurship and cooperation development: institutional aspect: monohr]. Kyiv. 430 p. (in Ukrainian)

9. Romanova L.V. (1997). Stanovlennia pidpryiemnytstva v silskomu hospodarstvi. [Formation of entrepreneurship in agriculture]. Kyiv. : IAE. 272 p. (in Ukrainian)

10. Shpykuliak O.H., Malik M.I. (2019). Instytutsionalnyi analiz rozvytku pidpryiemnytstva v ahrarnomu sektori ekonomiky: metodychnyi aspekt.[Institutional analysis of entrepreneurship development in agricultural sector of economy: methodical aspect]. Ekonomika APK, no. 6, p. 73-82. (in Ukrainian)

11. Sava A. P., Saienko M. H., Oliinyk O.R. (2015) Naukovo-praktychni rekomendatsii z obgruntuvannia metodychnykh pidkhodiv shchodo efektyvnoi restrukturyzatsii ahrarnoi haluzi v umovakh staloho rozvytku silskykh terytorii [Scientific and practical recommendations for substantiation of methodological approaches to the effective restructuring of the agricultural sector in the conditions of sustainable development of rural areas]. Ternopil. 2015. 80 p. (in Ukrainian).

12. Sabluk P.T. (2011). Orhanizatsiyno-ekonomichna modernizatsiya ahrarnoyi sfery [Organizational and economic modernization of the agricultural sector]. Kyiv: NNTs IAE, p. 342. (in Ukrainian)

13. Lupenko Yu.O., Malik M.I., Bulavka O.H. (2020) Stratehichni napriamy staloho rozvytku silskykh terytorii na period do 2030 roku [Strategic directions for sustainable rural development for the period up to 2030]. Kyiv.: NNTs IAE. 60 p. (in Ukrainian).

14. Shpykuliak O.H., Voskobiinyk Yu.P., Ovsiannikov O.V. (2007). Vytraty ta efektyvnist vyrobnytstva produktsii v silskohospodarskykh pidpryiemstvakh (monitorynh) [Costs and efficiency of production in agricultural enterprises (monitoring)]. Kyiv. 294 p. (in Ukrainian)

15. Shpykuliak O.H. (2007). Stanovlennia sotsialnoho kapitalu v ahrarnii sferi transformatsiinoi ekonomiky. [Formation of social capital in the agrarian sphere of transformation economy]. Management Theory and Studies for Rural Business and Infrastructure Development, vol. 8, pp. 28-34. Available at: http://mts.asu.lt/mtsrbid/article/view/678/704. (accessed 23 March 2020).

16. Shpykuliak O.H. (2017). Teoretychni zasady rozvytku pidpryiemnytstva v instytutsiinomu mekhanizmi rynku [Theoretical principles of entrepreneurship development in the institutional mechanism of the market]. Rozvytok malykh ahrarnykh pidpryiemstv v rynkovomu instytutsiinomu seredovyshchi: indykatory ta efektyvnist: monohrafiia. Natsionalnyi naukovyi tsentr «Instytut ahrarnoi ekonomiky»]. Kyiv. NNTs «IAE». pp. 8-12. (in Ukrainian).

17. The official site of the State Statistics Service of Ukraine. Available at: http://www.ukrstat.gov.ua (accessed 26 March 2020).

\section{СОЦИАЛЬНО-ЭКОНОМИЧЕСКАЯ РЕЗУЛЬТАТИВНОСТЬ СЕЛЬСКОХОЗЯЙСТВЕННОГО ПРЕДПРИНИМАТЕЛЬСТВА: РЕГИОНАЛЬНЫЙ АСПЕКТ ОЦЕНКИ}

В статье рассмотрены теоретико-методические характеристики научного позиционирования соииальноэкономической результативности сельскохозяйственного предпринимательства. Предложен научно обоснованный подход к определению социально-экономической результативности и основы различий от понятия сочиально-экономической эффективности предпринимательского хозяйствования. Охарактеризована связь деятельности в сельскохозяйственном предпринимательстве с развитием сельских территорий, говорится о региональной специфике значимости агробизнеса для села, формирования продовольственной безопасности. Доказана сущность предпринимательства как сочиального и экономического явления, обеспечивающего сочиально-экономическую результативность. Проанализирована связь структуры сельскохозяйственного производства, региональные особенности по доле валовой продукиии как базовый индикатор соииально-экономической результативности предпринимательства. Определена перспективность дальнейшего исследования предпринимательства с представлением все большей значимости отрасли в условиях экономической неопределенности.

Ключевые слова: предпринимательство, сельскохозяйственное предпринимательство, социально-экономическая результативность, хозяйствования, производительность, региональное развитие. 


\section{SOCIO-ECONOMIC RESULTS OF AGRICULTURAL ENTERPRISE: A REGIONAL ASPECT OF ASSESSMENT}

The article deals with the theoretical and methodological characteristics of the scientific positioning of socio-economic performance of agricultural entrepreneurship. The scientifically grounded approach to the definition of socio-economic efficiency and the basis of differences from the concept of socio-economic efficiency of business management is proposed. The connection of activity in agricultural enterprise with the development of rural territories is described, the regional specificity of the importance of agribusiness for the country, the formation of food security are stated. The essence of entrepreneurship as a social and economic phenomenon that provides socio-economic efficiency is proved. The theoretical basis of the essence and methodological criteria for understanding the social price of production are determined. The relation of social price and social responsibility in agricultural enterprise is given. The methodical distribution of socio-economic performance of business management by level: territorial and economic. Structural factors of formation of socio-economic efficiency of entrepreneurial activity in agriculture are determined on the basis of traditions of the village conservation model of management. The relationship of agricultural production structure, regional peculiarities by share is analyzed. Gross production as a basic indicator of socio-economic performance of entrepreneurship. Structural distribution of regions (oblasts) of Ukraine by maximum and minimum share in the national production of gross output of the agricultural sector is carried out. Regional trends of development of agricultural enterprises by socio-economic indicators have been worked out. The prospect of further study of entrepreneurship with the presentation of increasing importance of the industry in conditions of economic uncertainty is outlined. Also important in Ukraine is the regional aspect of solving the problem, it is pronounced, transformed into a way of rural life. This issue requires further research to be promising for scientific knowledge, especially in the face of uncertainty about the prospects of other industries, as well as a growing understanding of the need to restructure the way social and economic life is organized.

Key words: entrepreneurship, agricultural entrepreneurship, socio-economic performance, management, productivity, regional development. 